\title{
Thermal performance evaluation of a bioclimatic ventilated wall using a Hot Box
}

\author{
Dwinanto Sukamto ${ }^{1,{ }^{*}}$, François Gloriant $^{1}$, Monica Siroux $^{1}$ \\ ${ }^{1}$ INSA de Strasbourg, ICUBE, University of Strasbourg, 24 Bld de la Victoire 67000, France
}

\begin{abstract}
Nowadays, external isolation is highly recommended for both building renovation and new building construction. This isolation requires the installation of structure protecting the insulating materials from the humidity and weather variations. One of the current techniques is the installation of ventilated facades. The recovered energy by this process could be used in winter for the preheating of ventilated air or could be evacuated in summer to protect the building from potential overheating. This study describes the design and application of Hot Box developed specifically to test the thermal performance of a ventilated bioclimatic wall. Based on experiments test, this paper discusses the experimental set-up and the thermal metrology. Data collected from testing a ventilated wall were used to estimate the convection heat transfer coefficients of the ventilated wall.
\end{abstract}

\section{Introduction}

Climate change is the major challenge facing the world in the future. In this context, France is placing the construction sector at the heart of its strategy to meet this challenge [1]. Saving energy is a priority in developed countries. The building sector is responsible for $40 \%$ of energy consumption in Europe [2]. The building envelope is the construction element that has the greatest impact on the overall energy consumption of the building [3][4]. It must be taken into account that the facade represents the interface between external environmental factors and the interior requirements of the occupants. In recent years, architecture has shown a particular interest in ventilated walls. It cannot be denied that there are a considerable number of studies and publications on "ventilated envelopes" [5][6][7], especially on double skin facades [8][9][10], building-integrated photovoltaics [11][12][13], solar chimneys, solar walls and Trombe walls [14][15][16], or façade solar collectors [17][18].

The ventilated facade is chosen by architects and contractors as an envelope solution in a wide variety of building types, climates and design configurations. The system offers a wide variety of exterior claddings and the ability to select a wide variety of materials, colors and panel sizes. In addition to the aesthetic aspect, the primary purpose of this type of façade is to protect the insulation materials by dissipating moisture. The objective of a bioclimatic design of a building is to achieve indoor comfort in the most "natural" way possible. For a given site, it is no longer just a question of protecting against the vagaries of the climate but also of enhancing its benefits. In this approach, we therefore seek to adapt the building to its environment as well as possible. The ventilated wall is a response to this approach. The objective of this study is to characterize the thermal performance of a bioclimatic ventilated wall. An original system has been set up for the experimental study of a bioclimatic ventilated wall. It is the relevance of this device that we discuss in this paper.

\section{Description of the experimental set up}

\subsection{Bioclimatic ventilated wall and Hot Box}

The ventilated wall is a wall with a non-hermetically insulated channel that participates in the supply of fresh air to the building; a convective exchange takes place in the cavity along the axis of the wall, which disturbs the radial heat flow between the interior and exterior environments (Figure 1). The air flowing inside the cavity is then preheated and introduced into the building. This system reduces the heating requirements of the building. The sample studied is composed of two grey walls $1 \mathrm{~m}$ high and $1 \mathrm{~m}$ wide. The first one is fixed while the second one is mobile, allowing the thickness of the ventilated cavity to be varied. These two walls are made of an aluminum alloy and polyethylene of $3 \mathrm{~mm}$ thickness and have a thermal resistance of $0.008 \mathrm{~m}^{2} . \mathrm{K} \mathrm{W}^{-1}$. Their surfaces are smooth (low roughness) with an emissivity of 0.9. The ventilated air gap is introduced inside the Hot Box (Figure 1). The Hot Box is a device composed of two climatic chambers capable of reproducing selected the temperature and relative humidity conditions. The range of temperature and humidity is from $-30^{\circ} \mathrm{C}$ to $+60^{\circ} \mathrm{C}$ and from $10 \%$ to $98 \%$. Each chamber has its own refrigeration unit guaranteeing the production of cold with a temperature accuracy of $\pm 2^{\circ} \mathrm{C}$. Each one also has 3 electric resistors of $2.5 \mathrm{~kW}$, guaranteeing the production of heat with a temperature accuracy of $\pm 3{ }^{\circ} \mathrm{C}[19]$. The

Corresponding author: dwinanto.sukamto@insa-strasbourg.fr 
Hot Box is connected to a computer to control the temperature and humidity parameters of each chamber.
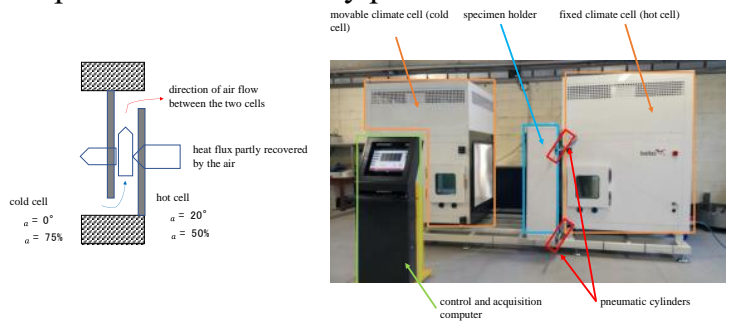

Fig. 1. Presentation of the ventilated wall (left) integrated to the sample holder of the Hot Box (right).

\subsection{Thermal metrology}

To characterize the thermal behaviour of the sample under study, the ventilated wall is equipped with type $\mathrm{K}$ thermocouples and flowmeters of the Captec Entreprise ${ }^{\circledR}$ brand, allowing the joint measurement of surface temperatures, the air inside and outside the cavity, as well as the estimation of heat flux on both sides of the ventilated cavity (Figure 2). In each of the climate cells, 3 thermocouples are used to determine the ambient temperatures. On each of the walls of the ventilated cavity, 12 thermocouples and 4 flux meters have been installed on 4 levels of different heights and are equally distributed over the width. For the measurement of the air temperature, 3 thermocouples have been placed at the entrance and 3 others at the exit of the cavity. Inside and in the middle of the cavity there are also 4 thermocouples. The airflow within the cavity is generated by means of a fan controlled by a voltage variator and the measurement of the flow rate is estimated by means of a CTV 210 hot wire anemometer from the manufacturer KIMO. All the sensors are connected to a Keithley $2700 \AA$ multimeter allowing a voltage measurement in the order of one-tenth of a microVolt. The multimeter itself is connected to a computer via the RS-232 serial communication channel. Data acquisition and processing are then carried out via the LabVIEW software. An infrared camera is also used to estimate the temperature of the hot wall of the device.

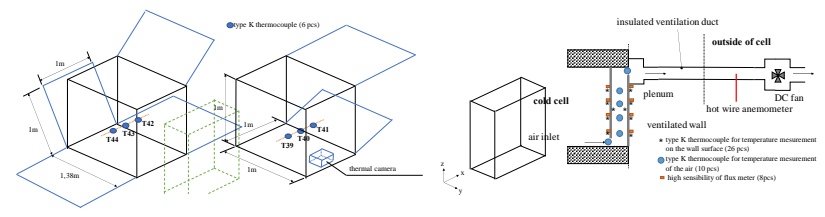

Fig. 2. Hot Box instrumentation.

\section{Results}

Several tests have been undertaken to ensure that the device works properly. For all these control tests, the ambient conditions were set at $20^{\circ} \mathrm{C}$ and $55 \%$ relative humidity for the fixed cell, and $0^{\circ} \mathrm{C}$ and $75 \%$ relative humidity for the mobile cell. The measurement readings are taken in a steady state, the airflow rate is $20 \mathrm{~m}^{3} \cdot \mathrm{h}^{-1}$ and flows from the mobile cell (cold environment) to the fixed cell (hot environment) in a cavity $0.01 \mathrm{~m}$ thick.

\subsection{Hot Box Temperatures}

The measurement of the ambient temperature in each of the cells of the Hot Box was carried out. A temperature difference of at least $20^{\circ} \mathrm{C}$ between the 2 cells was aimed at obtaining heat fluxes high enough to be correctly measured by the flux meters. [20].
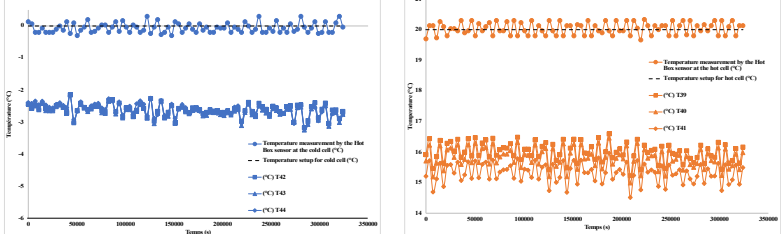

Fig. 3. Ambient temperature measurements in the cold cell (left) and in the hot cell (right).

With the setpoints considered $\left(20^{\circ} \mathrm{C}\right.$ in the fixed cell and $0^{\circ} \mathrm{C}$ in the mobile cell), we observe for each of the cells, a significant difference on the measurement of the ambient temperature between the integrated sensor of the Hot Box and the thermocouple measurements (Figure 3). One cannot trust the temperature sensor integrated in the Hot Box because it overestimates the ambient temperature by $2.6^{\circ} \mathrm{C}$ for the mobile cell and by $4.3^{\circ} \mathrm{C}$ for the fixed cell. This inaccuracy can partly be explained by the fact that the cells are not airtight since an artificial airflow has been created between them. However, for standard use of the Hot Box, there should be no air exchange between the cells; the regulation system of the device is then disturbed. Moreover, it can be seen that the air circulation is sufficient to obtain a homogeneous temperature distribution in time and space. On average, the maximum measuring difference between the thermocouples is $0.04^{\circ} \mathrm{C}$ in the mobile cell and $0.7^{\circ} \mathrm{C}$ in the fixed cell.

\subsection{Surface temperatures}

Measurement of surface temperatures is done by thermocouples. Thermocouple's measurements are compared to that obtained using an infrared camera. The area covered by the infrared camera has a surface area of $10 \mathrm{~cm}^{2}$. The T8 and T5 thermocouples are located on the upper and lower part of this surface (Figure 4).

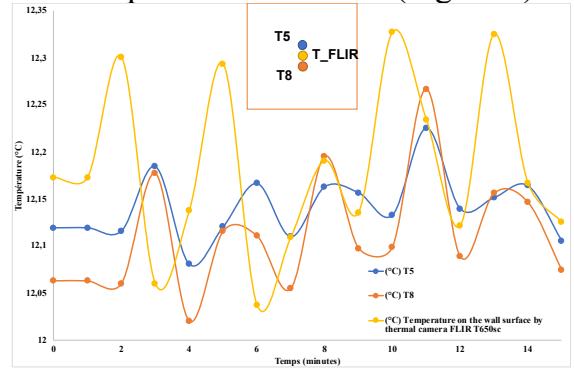

Fig. 4. Surface temperatures.

It can be observed that the temperature measurements of each of the sensors are stable over time and are quite close together. The averages over the period considered for the thermocouples $\mathrm{T} 5, \mathrm{~T} 8$ and the infrared camera are $12.14^{\circ} \mathrm{C}, 12.11^{\circ} \mathrm{C}$ and $12.18^{\circ} \mathrm{C}$ respectively. It is an expected result to obtain a slightly higher temperature at the T5 thermocouple level than at the T8 thermocouple level [20]. Indeed, the air circulating in the wall heats up little by recovering part of the thermal flow coming from 
the hot cell. Thus, the wall adjacent to the cold cell, which is in contact with this increasingly hot air, also heats up along the cavity. By averaging the temperature with thermocouples T5 and T8, we obtain an average temperature over the surface covered by the infrared camera. We can then see that the measurement difference between these 2 types of probes is $0.05^{\circ} \mathrm{C}$. The measurements of surface temperatures by the thermocouples are in adequacy with the measurements made by the infrared camera and confirm the reliability of the instrumentation of the walls.

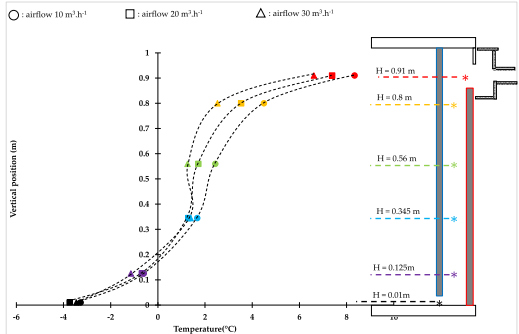

Fig. 5. Air temperature in the ventilated chamber.

Figure 5 presents the air temperature in the ventilated chamber as a function of vertical position $\mathrm{H}$ for an air space thickness of $50 \mathrm{~mm}$ and for different airflow rate $\left(10 \mathrm{~m}^{3} \cdot \mathrm{h}^{-1}, 20 \mathrm{~m}^{3} \cdot \mathrm{h}^{-1}\right.$ and $\left.30 \mathrm{~m}^{3} \cdot \mathrm{h}^{-1}\right)$. It can be seen that in the top of the air chamber, the air temperature decreases with the airflow rate. This indicates that the efficiency of the ventilated wall decreases with the airflow rate.

\subsection{The convection heat transfer coefficient}

The objective is to quantify the convection heat transfer coefficient between the ventilated bioclimatic wall and the atmospheres of each of the cells. We considered 2 distinct air gap thicknesses $(0.005 \mathrm{~m}$ and $0.01 \mathrm{~m})$ and 3 airflows $\left(10 \mathrm{~m}^{3} \cdot \mathrm{h}^{-1}, 20 \mathrm{~m}^{3} \cdot \mathrm{h}^{-1}\right.$ and $\left.30 \mathrm{~m}^{3} \cdot \mathrm{h}^{-1}\right)$.

The joint use of thermocouples and fluxmeters allows an experimental estimation of these exchange coefficients without using existing correlations. To estimate these parameters, we use Newton's law:

$$
h=q /\left(T_{s}-T_{a}\right)
$$

According to this relation, the estimation of the convection heat transfer coefficient $h$, requires the knowledge of the heat flux $q$, the ambient air temperature in the cell Ta and of the wall surface temperature $T s$.

Since each wall of the sample is equipped, at different heights, with 4 flux meters and 4 thermocouples, it is possible to obtain 4 local estimates of the heat transfer coefficient per cell. For the ambient temperature in each of the cells, a single air temperature is considered, corresponding to the average of the measurements of the 3 thermocouples installed in each cell.

Figure 5 shows the estimates of the heat transfer coefficient at the wall surface in each of the cells and for different cavity thicknesses and flow rates. The coefficient $h$ varies between $15 \mathrm{~W} . \mathrm{m}^{-2} \cdot \mathrm{K}^{-1}$ and $24 \mathrm{~W} . \mathrm{m}^{-}$ ${ }^{2} \cdot \mathrm{K}^{-1}$ over the set of tests with a mean of $20.4 \pm 2.7 \mathrm{~W} . \mathrm{m}^{-}$ ${ }^{2} \cdot \mathrm{K}^{-1}$ for the mobile cell and $18.4 \pm 1.5 \mathrm{~W} \cdot \mathrm{m}^{-2} \cdot \mathrm{K}^{-1}$ for the fixed cell. This order of magnitude is consistent with the correlations that can be found in the literature [21]. It can be noted that neither the thickness of the cavity nor the flow of air in the wall has any real influence on the estimates of the coefficient $h$. This means that these 2 parameters have no influence on the ambiances of the 2 climate cells. On the other hand, the coefficient $h$ depends on the position at which it has been calculated and it can be seen that, for a given height, the estimates of the coefficient $h$ are relatively homogeneous[22].

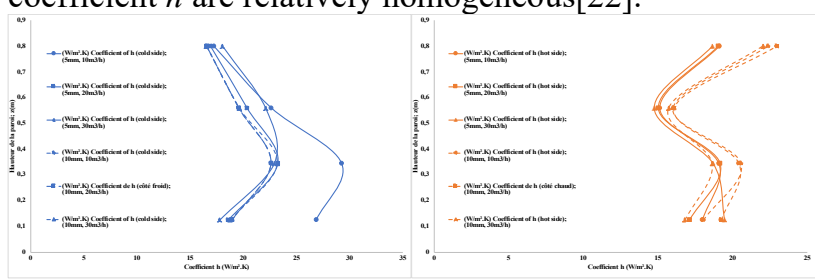

Fig. 6. The convection heat transfer coefficient in the cold cell (left) and in the hot cell (right).

The results concerning the uncertainties for the convection heat transfer coefficient $h$ (Table 1) are globally satisfactory. An uncertainty of 5\% was considered for flux meters and uncertainty of $0.02^{\circ} \mathrm{C}$ for thermocouples. It can be seen that the uncertainties are smaller in the hot cell as the fluxes and temperature differences involved are larger. It is in the cold cell, at the lower part of the wall, that the uncertainties are the greatest; at this point, the temperatures between the wall and the environment of the cold cell are very close and often of the order of a tenth of a degree.

Table 1. Uncertainties for the convection heat transfer coefficient.
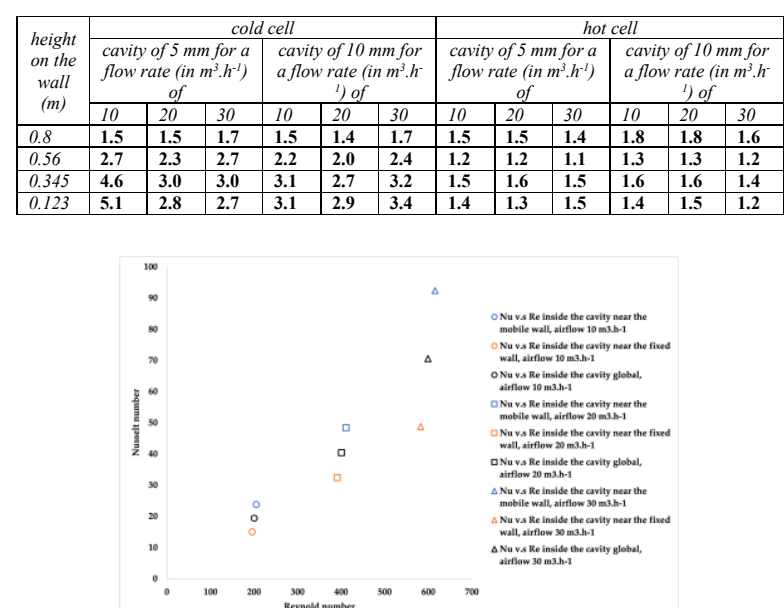

Fig. 7. Nusselt number in the ventilated chamber.

Figure 7 presents the local and global Nusselt number in the ventilated chamber as a function of Reynolds number for an air space thickness of $50 \mathrm{~mm}$ and for different airflow rates $\left(10 \mathrm{~m}^{3} \cdot \mathrm{h}^{-1}, 20 \mathrm{~m}^{3} \cdot \mathrm{h}^{-1}\right.$ and $\left.30 \mathrm{~m}^{3} \cdot \mathrm{h}^{-1}\right)$. Experimental results shows that the local and global Nusselt number increases with the airflow rate.

\section{Conclusion}

The purpose of this study was to investigate the thermal performance of a ventilated bioclimatic wall. For this reason, the Hot Box thermal metrology was developed specifically. Based on experiments test, this study discusses the experimental set-up and the thermal 
metrology. Data collected from the Hot Box were used to estimate the convection heat transfer coefficients of the ventilated wall. This study was completed by an analysis of the measurement uncertainties, which proved satisfactory.

\section{References}

1. Bâtiments à énergie positive et réduction carbone, (2019) 3-5. http://www.batimentenergiecarbone.fr/contexte-a2.html.

2. E. Commission, Evaluation of the Energy Performance of Building Directive 2010/31/EU, $2015 . \quad$ http://ec.europa.eu/smartregulation/evaluation/index_en.htm.

3. G. Manioğlu, Z. Yılmaz, Economic evaluation of the building envelope and operation period of heating system in terms of thermal comfort, Energy Build. 38 (2006) 266-272. https://doi.org/10.1016/j.enbuild.2005.06.009.

4. R. Pacheco, J. Ordóñez, G. Martínez, Energy efficient design of building: A review, Renew. Sustain. Energy Rev. 16 (2012) 3559-3573. https://doi.org/10.1016/j.rser.2012.03.045.

5. L.F. Cabeza, A. De Gracia, A. Castell, L. Navarro, E. Oro, Numerical modelling of ventilated facades : A review, 22 (2013) 539-549. https://doi.org/10.1016/j.rser.2013.02.029.

6. H.Y. Chan, S.B. Riffat, J. Zhu, Review of passive solar heating and cooling technologies, Renew. Sustain. Energy Rev. 14 (2010) 781-789. https://doi.org/10.1016/j.rser.2009.10.030.

7. C.M. Lai, S. Hokoi, Solar façades: A review, Build. Environ. $\quad 91 \quad$ (2015) 152-165. https://doi.org/10.1016/j.buildenv.2015.01.007.

8. S. Barbosa, K. Ip, Perspectives of double skin façades for naturally ventilated buildings: A review, Renew. Sustain. Energy Rev. 40 (2014) 1019-1029. https://doi.org/10.1016/j.rser.2014.07.192.

9. A. Pappas, Z. Zhai, Numerical investigation on thermal performance and correlations of double skin façade with buoyancy-driven airflow, Energy Build. $40 \quad$ (2008) 466-475. https://doi.org/10.1016/j.enbuild.2007.04.002.

10. M.A. Shameri, M.A. Alghoul, K. Sopian, M.F.M. Zain, O. Elayeb, Perspectives of double skin façade systems in buildings and energy saving, Renew. Sustain. Energy Rev. 15 (2011) 1468-1475. https://doi.org/10.1016/j.rser.2010.10.016.

11. G. Quesada, D. Rousse, Y. Dutil, M. Badache, S. Hallé, A comprehensive review of solar facades. Opaque solar facades, Renew. Sustain. Energy Rev.
16
(2012)
$2820-2832$

https://doi.org/10.1016/j.rser.2012.01.078.

12. I. Cerón, E. Caamaño-Martín, F.J. Neila, "State-ofthe-art" of building integrated photovoltaic products, Renew. Energy. 58 (2013) 127-133. https://doi.org/10.1016/j.renene.2013.02.013.

13. O. Zogou, H. Stapountzis, Experimental validation of an improved concept of building integrated photovoltaic panels, Renew. Energy. 36 (2011) 3488-3498. https://doi.org/10.1016/j.renene.2011.05.034.

14. D.J. Harris, N. Helwig, Solar chimney and building ventilation, Appl. Energy. 84 (2007) 135-146. https://doi.org/10.1016/j.apenergy.2006.07.001.

15. R. Khanal, C. Lei, Solar chimney-A passive strategy for natural ventilation, Energy Build. 43 (2011) 1811-1819. https://doi.org/10.1016/j.enbuild.2011.03.035.

16. O. Saadatian, K. Sopian, C.H. Lim, N. Asim, M.Y. Sulaiman, Trombe walls: A review of opportunities and challenges in research and development, Renew. Sustain. Energy Rev. 16 (2012) 6340-6351. https://doi.org/10.1016/j.rser.2012.06.032.

17. L.H. Gunnewiek, E. Brundrett, K.G.T. Hollands, Flow distribution in unglazed transpired plate solar air heaters of large area, Sol. Energy. 58 (1996) 227237. 092X(96)00083-7. https://doi.org/10.1016/S0038-

18. M.A. Leon, S. Kumar, Mathematical modeling and thermal performance analysis of unglazed transpired solar collectors, Sol. Energy. 81 (2007) 62-75. https://doi.org/10.1016/j.solener.2006.06.017.

19. I. Entreprise, Manual Usuario, Ineltec Entreprise, n.d.

20. F. Gloriant, P. Tittelein, A. Joulin, S. Lassue, Study Of The Performances Of A Supply-Air Window For Air Renewal Pre-Heating, Energy Procedia. 78 (2015) $525-530$. https://doi.org/10.1016/j.egypro.2015.11.727.

21. J. Padet, Convection thermique et massique Principes généraux, 33 (2005) 0-23. https://wwwtechniques-ingenieur-fr.ezproxy.insastrasbourg.fr/base-documentaire/energiesth4/transferts-thermiques-42214210/convectionthermique-et-massique-be8205/.

22. D. Sukamto, M. Siroux, F. Gloriant, Hot Box Investigations of a Ventilated Bioclimatic Wall for NZEB Building Façade, Energies. 14 (2021) 1327. https://doi.org/10.3390/en14051327. 